FOLIA POMERANAE UNIVERSITATIS TECHNOLOGIAE STETINENSIS

Folia Pomer. Univ. Technol. Stetin., Oeconomica 2018, 344(91)2, 5-12

Grzegorz BUCIOR

\title{
PLANY ZAWODOWE STUDENTÓW A AKREDYTACJA NA UCZELNIACH - BADANIE WŚRÓD STUDENTÓW KIERUNKU FINANSE I RACHUNKOWOŚĆ
}

\section{STUDENTS CAREER PLANS VS. ACCREDITATION OF THE UNIVERSITY - THE POLL AMONG FINANCE AND ACCOUNTING COURSE STUDENTS}

Katedra Rachunkowości, Uniwersytet Gdański

ul. Armii Krajowej 101, 81-824 Sopot, e-mail:grzegorz@bucior.pl

\begin{abstract}
Summary. The aim of this article is to examine the relationship between the carrer plans of students in Finance and Accounting at the Faculty of Management at the University of Gdańsk and their perception of the accreditation and certification of professional financial institutions. Using research primarily based on student surveys, responses to questions about students' perceptions of the importance of certificates and professional qualifications, based on their professional plans, in particular the form of work or the size of the future employer, are formulated. The analysis of the results of the survey allows us to conclude that students planning to work in small and medium enterprises perceive the qualifications awarded by international organizations such as ACCA, CIMA or CFA as unnecessary in their future work. For those students, spending more on learning in return for facilitating the acquisition of professional qualifications is not justified. The basic conclusion from the research can be a guideline for people who construct the curriculum structure and curriculum content - it is justified to diversify the educational offer by allowing them to pursue financial studies accredited by the professors and without such accreditation.
\end{abstract}

Słowa kluczowe: kwalifikacje zawodowe, ACCA, CIMA, CFA, SKwP, zawodowe plany studentów, finanse i rachunkowość.

Key words: qualification for professionals, ACCA, CIMA, CFA, SKwP, student's career plans, finance and accounting.

\section{WSTĘP}

Realizowane w ostatnich latach zmiany w szkolnictwie wyższym wynikają z konieczności dostosowania oferty edukacyjnej do szybko zmieniających się warunków wpływających na rynek pracy (Reforma Szkolnictwa Wyższego 2011). Podmioty kształtujące politykę edukacyjną, zarówno na poziomie krajowym, jak i międzynarodowym, wskazują, iż uczelnie wyższe powinny:

- zaspokajać bieżące i przyszłe zapotrzebowanie na wykwalifikowanych pracowników, z uwzględnieniem wymogu dostosowania się do rosnącej konkurencji, zmian w strukturze zatrudnienia i rozwoju technologii informacyjnych (Komunikat Komisji... 2010; Pavlin i in. 2016);

- gwarantować włączenie komponentu zawodowego pozwalającego na nabycie realnych umiejętności profesjonalnych (Rezolucja ... 2011). 
Badania wskazują, iż realizacja wyżej wymienionych celów możliwa jest jedynie dzięki współpracy uczelni z instytucjami mającymi wpływ na funkcjonowanie rynków pracy w poszczególnych branżach (Ryan 2012; Parlow i in. 2016). W literaturze dominuje pogląd, iż kluczowa w tym zakresie jest współpraca uczelni z organizacjami nadającymi i potwierdzającymi kwalifikacje zawodowe (Montano i in. 2001; Annisette i in. 2007). W szczególny sposób dotyczy to profesji z obszaru finansów i rachunkowości ze względu na:

- regulacje ograniczające dostęp do świadczenia niektórych usług w tej branży przez osoby posiadające określone kwalifikacje (Walińska i in. 2013);

- jednoznacznie pozytywne postrzeganie przez pracodawców znaczenia posiadanych przez pracownika kwalifikacji i certyfikatów (Świetla 2012);

- prestiż, jakim cieszą się kwalifikacje zawodowe nadawane przez uznane organizacje branżowe (Gryn 2011; Discover ACCA 2016).

Obserwacja działań uczelni w opisywanym obszarze prowadzi do wniosku, iż uniwersytety kształcące przyszłych finansistów i księgowych nadały istotną rangę współpracy z profesjonalnymi organizacjami certyfikującymi zawody z branży finansowej (Bucior i Zackiewicz 2015). Działania te dotyczą przede wszystkim:

- uzyskania certyfikatu gwarantującego absolwentowi uczelni ułatwienia w zdobyciu kwalifikacji zawodowych nadawanych przez profesjonalne organizacje branżowe, takie jak Association of Chartered Certified Accountants (ACCA), Chartered Institute of Management Accountants (CIMA), Chartered Financial Analyst (CFA), Certified Management Accountant (CMA), Stowarzyszenie Księgowych w Polsce (SKwP);

- uzyskania certyfikatu potwierdzającego odpowiedni poziom nauczania nadawany przez organizacje, takie jak International Accreditation Council for Business Education (IACBE), Association to Advance Collegiate Schools of Business (AACSB), Association of MBA (AMBA). Uzyskanie akredytacji dla całej uczelni bądź kierunków na polskich uniwersytetach osiągane jest sporym nakładem sił i środków, co wynika z wysokich wymagań, jakie formułują organizacje certyfikujące, a które dotyczą: treści programowych, ilości godzin czy metod i technik dydaktycznych (Bucior i Kujawski 2017). Dzieje się tak, mimo że rozpoznawalność organizacji nadających kwalifikacje czy certyfikaty wśród studentów jest niewielka (Bucior i Spigarska 2017). Również niewielka jest znajomość zasad i znaczenia kwalifikacji oferowanych przez poszczególne organizacje. Jednocześnie badania potwierdzają, iż studenci pozytywnie odnoszą się do możliwości uzyskania ułatwień w zdobyciu kwalifikacji zawodowych dzięki studiowaniu na akredytowanych wydziałach bądź kierunkach, nawet jeśli wiązać by się to miało z ponadstandardowym nakładem pracy czy ponoszeniem określonych kosztów (Prewysz-Kwinto i Voss 2016). Interesujące jest w tym kontekście określenie przesłanek pozytywnego lub negatywnego postrzegania przez studentów kierunków finansowych współpracy uczelni z organizacjami certyfikującymi. Założyć można, iż poziom akceptacji przez studentów zwiększonego wysiłku, jaki muszą włożyć w naukę w zamian za uzyskanie kwalifikacji lub ułatwień w ich uzyskaniu, różni się w zależności od planów zawodowych po zakończeniu studiów.

Celem artykułu jest zbadanie relacji pomiędzy planami zawodowymi studentów kierunku finanse i rachunkowość, studiujących na Wydziale Zarządzania Uniwersytetu Gdańskiego, a postrzeganiem przez nich działań uczelni polegających na uzyskaniu akredytacji i certyfikacji 
profesjonalnych podmiotów z branży finansowej. Na podstawie badań opisanych poniżej autor zamierza uzyskać odpowiedź na pytanie: Czy studenci w różny sposób oceniają wartość certyfikatów i kwalifikacji zawodowych w zależności od swoich planów zawodowych dotyczących w szczególności formy pracy lub wielkości przedsiębiorstwa przyszłego pracodawcy? Odpowiedź może być pomocna przy konstruowaniu oferty edukacyjnej kierowanej do studentów.

\section{MATERIA I METODY}

W pracy korzystano z trzech podstawowych metod badawczych:

1) z badania materiałów źródłowych związanych z akredytacjami uzyskanymi przez uczelnie ekonomiczne (bądź ekonomiczne wydziały szkół wyższych), wydawanymi przez certyfikujące organizacje, dostępne na stronach internetowych uczelni;

2) z przeglądu publikacji dotyczących badań w obszarze relacji i współpracy pomiędzy uczelniami a podmiotami akredytującymi i certyfikującymi programy nauczania;

3) z badania ankietowego wykonanego w celowo dobranej grupie studentów.

Na potrzeby realizacji celu artykułu zostało przeprowadzone badanie ankietowe charakteryzujące się cechami opisanymi poniżej:

1. Badanie zostało przeprowadzone wśród studentów kierunku finanse i rachunkowość studiujących na Wydziale Zarządzania Uniwersytetu Gdańskiego.

2. Ankietę wypełniło 465 studentów studiów stacjonarnych oraz niestacjonarnych.

3. Ankieta była przeprowadzona w październiku i listopadzie 2017 r.

4. Analizą objęto 452 ankiety, ponieważ 13 arkuszy nie zostało wypełnionych bądź zostało wypełnionych wadliwie w stopniu uniemożliwiającym ocenę wyniku.

5. Formularz ankietowy składał się z 20 pytań, z czego analizą w niniejszym artykule objęto 9.

\section{WYNIKI I DYSKUSJA}

Analizowane w pracy pytania przedstawione są w tab. 1 .

Tabela 1. Opis ankietowych pytań

\begin{tabular}{|c|c|c|}
\hline Lp. & Pytanie & Sugerowana odpowiedź/ odpowiedzi \\
\hline 1 & $\begin{array}{l}\text { Analizując dotychczasowy mój } \\
\text { przebieg studiów, uważam, że }\end{array}$ & $\begin{array}{l}\text { jedna lub więcej odpowiedzi: } \\
\text { a) dobrze wybrałem kierunek studiów } \\
\text { b) nie jestem jeszcze przekonany, czy dobrze wybrałem kierunek } \\
\text { studiów } \\
\text { c) rozważam zmianę kierunku studiów } \\
\text { d) wybrałbym inny kierunek, gdybym mógł wybierać ponownie }\end{array}$ \\
\hline 2 & Swoją karierę zawodową & $\begin{array}{l}\text { jedna odpowiedź: } \\
\text { a) wiążę z pracą w księgowości } \\
\text { b) wiążę z pracą w ogólnie rozumianej branży finansowej } \\
\text { c) żadna z powyższych }\end{array}$ \\
\hline 3 & $\begin{array}{l}\text { Jeśli wiążesz swoje plany zawo- } \\
\text { dowe z pracą w księgowości/ } \\
\text { finansach, to dotyczy to pracy }\end{array}$ & $\begin{array}{l}\text { jedna odpowiedź: } \\
\text { a) w małej/ średniej firmie } \\
\text { b) w dużej firmie/ korporacji } \\
\text { c) jako samodzielny pracownik (doradca, biegły, księgowy usługowo } \\
\text { prowadzący rachunkowość) } \\
\text { d) w sektorze publicznym } \\
\text { e) nie dotyczy }\end{array}$ \\
\hline
\end{tabular}


Tabela 1. Opis ankietowych pytań (cd.)

\begin{tabular}{|c|c|c|}
\hline 4 & $\begin{array}{l}\text { Która z poniższych kwalifikacji } \\
\text { jest ci znana? }\end{array}$ & $\begin{array}{l}\text { jedna lub więcej odpowiedzi: } \\
\text { a) ACCA (Association of Chartered Certified Accountants ) } \\
\text { b) biegły rewident } \\
\text { c) dyplomowany księgowy (nadawana przez SKwP) } \\
\text { d) doradca podatkowy } \\
\text { e) CIMA (Chartered Institute of Management Accountants) } \\
\text { f) CFA (Chartered Financial Analyst) } \\
\text { g) żadnej z wymienionych kwalifikacji nie znam }\end{array}$ \\
\hline 5 & $\begin{array}{l}\text { Którą z wymienionych kwalifikacji } \\
\text { uznajesz za przydatną w pla- } \\
\text { nowanej pracy zawodowej? }\end{array}$ & $\begin{array}{l}\text { jedna lub więcej odpowiedzi: } \\
\text { a) ACCA (Association of Chartered Certified Accountants ) } \\
\text { b) biegły rewident } \\
\text { c) dyplomowany księgowy (nadawana przez SKwP) } \\
\text { d) doradca podatkowy } \\
\text { e) CIMA (Chartered Institute of Management Accountants) } \\
\text { f) CFA (Chartered Financial Analyst) } \\
\text { g) żadna z wymienionych }\end{array}$ \\
\hline 6 & $\begin{array}{l}\text { Czy jesteś w trakcie zdobywania } \\
\text { którejś z wymienionych kwalifi- } \\
\text { kacji? }\end{array}$ & $\begin{array}{l}\text { jedna lub więcej odpowiedzi: } \\
\text { a) ACCA (Association of Chartered Certified Accountants ) } \\
\text { b) biegły rewident } \\
\text { c) dyplomowany księgowy (nadawana przez SKwP) } \\
\text { d) doradca podatkowy } \\
\text { e) CIMA (Chartered Institute of Management Accountants) } \\
\text { f) CFA (Chartered Financial Analyst) } \\
\text { g) nie }\end{array}$ \\
\hline 7 & $\begin{array}{l}\text { Czy uważasz, że uczelnia po- } \\
\text { winna akredytować programy } \\
\text { nauczania, tak aby absolwent } \\
\text { mógł uzyskać kwalifikację zawo- } \\
\text { dową bądź ułatwienia w jej } \\
\text { zdobyciu? }\end{array}$ & $\begin{array}{l}\text { jedna odpowiedzi: } \\
\text { a) nie } \\
\text { b) tak pomimo dodatkowych nakładów i kosztów, jakie będą ponosić } \\
\text { studenci } \\
\text { c) tak, ale tylko wtedy, gdy nie będzie wiązać się to z koniecznością } \\
\text { poniesienia dodatkowych nakładów (więszą ilością nauki bądź z do- } \\
\text { datkowymi kosztami) } \\
\text { d) nie mam zdania }\end{array}$ \\
\hline 8 & $\begin{array}{l}\text { Jeśli w poprzednim pytaniu za- } \\
\text { znaczyłeś odpowiedź b) lub c), } \\
\text { to wskaż, jakie kwalifikacje uczel- } \\
\text { nia powinna akredytować }\end{array}$ & $\begin{array}{l}\text { jedna lub więcej odpowiedzi: } \\
\text { a) ACCA (Association of Chartered Certified Accountants ) } \\
\text { b) biegły rewident } \\
\text { c) dyplomowany księgowy (kwalifikację nadawaną przez Stowarzysze- } \\
\text { nie Księgowych w Polsce) } \\
\text { d) doradca podatkowy } \\
\text { e) CIMA (Chartered Institute of Management Accountants) } \\
\text { f) CFA (Chartered Financial Analyst) } \\
\text { g) żadne z powyższych }\end{array}$ \\
\hline 9 & Na jakim kierunku studiujesz? & $\begin{array}{l}\text { jedna odpowiedzi: } \\
\text { a) FiR, specjalność rachunkowość, studia stacjonarne } \\
\text { b) FiR, specjalność rachunkowość ACCA, studia stacjonarne } \\
\text { c) FiR, specjalność rachunkowość, studia niestacjonarne } \\
\text { d) FiR, specjalność biegły rewident, studia stacjonarne } \\
\text { e) żaden z powyższych }\end{array}$ \\
\hline
\end{tabular}

Tabela 2 przedstawia odpowiedzi respondentów na podane w tab. 1 pytania.

Tabela 2. Odpowiedzi na pytania ankiety

\begin{tabular}{|c|c|c|c|c|c|c|c|}
\hline \multirow{2}{*}{$\begin{array}{c}\text { Numer } \\
\text { pytania }\end{array}$} & \multicolumn{9}{|c|}{ Odpowiedzi respondentów [\%] } & \multicolumn{4}{c|}{} \\
\cline { 2 - 9 } & $\mathrm{a}$ & $\mathrm{b}$ & $\mathrm{c}$ & $\mathrm{d}$ & $\mathrm{e}$ & $\mathrm{f}$ & $\mathrm{x}$ \\
\hline 1 & 67 & 27 & 0 & 6 & $\mathrm{x}$ & $\mathrm{x}$ & $\mathrm{x}$ \\
\hline 2 & 79 & 15 & 6 & $\mathrm{x}$ & $\mathrm{x}$ & $\mathrm{x}$ & $\mathrm{x}$ \\
\hline 3 & 42 & 40 & 16 & 2 & 14 & 2 & 0 \\
\hline 4 & 63 & 90 & 58 & 71 & 7 & 0 & 11 \\
\hline 5 & 37 & 39 & 46 & 28 & 0 & 0 & 74 \\
\hline 6 & 10 & 11 & 5 & 1 & $\mathrm{x}$ & $\mathrm{x}$ & $\mathrm{x}$ \\
\hline 7 & 16 & 44 & 38 & 2 & 15 & 9 & 0 \\
\hline 8 & 44 & 48 & 61 & 22 & 0 & $\mathrm{x}$ & $\mathrm{x}$ \\
\hline 9 & 66 & 25 & 266 & 89 & & & \\
\hline
\end{tabular}


Odpowiedzi respondentów na pytanie numer 4, dotyczące znajomości certyfikatów i kwalifikacji z branży finansowej, potwierdzają wyniki opublikowanych ostatnio badań (Prewysz-Kwinto i Voss 2016; Szadziewska i Kujawski 2016a, b) - większość studentów rozpoznaje kwalifikacje i uprawnienia krajowe (biegły rewident, dyplomowany księgowy, doradca podatkowy). Natomiast znajomość kwalifikacji nadawanych przez organizacje międzynarodowe jest niewielka, poza znajomością kwalifikacji ACCA. Wysoki poziom znajomości tej kwalifikacji wśród studentów należy tłumaczyć funkcjonowaniem specjalności rachunkowość ACCA na kierunku finanse i rachunkowość (studia stacjonarne) oraz studiami podyplomowymi „Rachunkowość ACCA”, co wiązało się między innymi z akcją promocyjną propagującą znaczenie kwalifikacji ACCA.

Pytanie numer 6 (Czy student jest w trakcie uzyskiwania kwalifikacji?) pokazuje, iż niewielka cześć respondentów rozpoczęła proces uzyskiwania kwalifikacji - co ciekawe, jednie 38\% studentów studiujących na specjalności rachunkowość ACCA rozpoczęło proces uzyskiwania kwalifikacji ACCA, mimo że wszczęcie tej procedury nie wiąże się z żadnymi kosztami, a wymaga jedynie dochowania niewielkich formalności.

Kluczowa dla niniejszego artykułu jest analiza odpowiedzi na pytanie 3 (o plany zawodowe) oraz pytanie 5 (o przydatność kwalifikacji). W odpowiedzi na pytanie o plany zawodowe $42 \%$ respondentów wskazało podmioty MŚP jako przyszłych pracodawców. Podobna część studentów planuje pracę w dużych przedsiębiorstwach. Znacznie mniej, bowiem jedynie $16 \%$, zakłada pracę na własny rozrachunek, co można uznać na potrzeby dalszej analizy za tożsame $z$ wolą podjęcia pracy dla sektora MŚP.

Biorąc pod uwagę wszystkich ankietowanych, za przydatne w pracy zawodowej:

- kwalifikacje ACCA uznaje 37\% respondentów,

- uprawnienia biegłego rewidenta uznaje 39\% respondentów,

- certyfikat dyplomowanego księgowego nadawany przez SKwP uznaje 46\% badanych,

- uprawnienia doradcy podatkowego uznaje $28 \%$ respondentów.

Symptomatyczne jest to, iż znaczny odsetek (11\%) studentów nie uznaje za przydatne w pracy zawodowej żadnych uprawnień i kwalifikacji.

Interesująco jawi się rozkład odpowiedzi na pytanie o przydatność kwalifikacji wśród studentów, którzy deklarują pracę w sektorze MŚP w charakterze księgowego (lub podobnym), co przedstawia tab. 3.

Tabela 3. Odpowiedzi na pytanie o przydatność kwalifikacji wśród studentów zamierzających pracować w sektorze MŚP

\begin{tabular}{|c|c|c|}
\hline \multirow{2}{*}{ Kwalifikacja } & Kwalifikacje przydatne & Kwalifikacje nieprzydatne \\
\hline & \multicolumn{2}{|c|}{$\%$} \\
\hline Biegły rewident & 31 & 69 \\
\hline Dyplomowany księgowy & 74 & 26 \\
\hline Doradca podatkowy & 66 & 34 \\
\hline ACCA & 22 & 78 \\
\hline CIMA & 15 & 75 \\
\hline CFA & 9 & 81 \\
\hline Żadna z wymienionych & 10 & 90 \\
\hline
\end{tabular}


Wyniki wyraźnie wskazują na to, iż studenci, którzy wiążą swoją drogę zawodową z małymi przedsiębiorstwami, nie postrzegają kwalifikacji nadawanych przez międzynarodowe organizacje jako pomocnych w karierze. Jeżeli już studenci dostrzegają korzyści z kwalifikacji, to raczej dotyczy to kwalifikacji krajowych, które dotyczą księgowych pracujących w sektorze MŚP. Świadczy o tym znaczny udział wskazań na certyfikat nadawany przez SKwP (74\%) oraz na uprawnienia doradcy podatkowego (66\%). Ten wniosek potwierdzają odpowiedzi na pytania 7 i 8 dotyczące zasadności działań podejmowanych przez uczelnię w celu uzyskania akredytacji profesjonalnych organizacji. Wprawdzie za takimi działaniami jest zdecydowana większość studentów (82\%, z czego 44\% niezależnie od konieczności poniesienia większego wysiłku przez studenta), jednak wśród studentów zamierzających pracować w sektorze MŚP jedynie 38\% dostrzega potrzebę uzyskania akredytacji przez uczelnię. Przy czym wśród tych studentów znacznie przeważają wskazania na podmioty krajowe: SKwP (91\% wskazań) oraz biegły rewident $(55 \%)$.

\section{PODSUMOWANIE}

Dostępna literatura przedmiotu potwierdza, iż w konsekwencji współpracy uczelni z organizacjami nadającymi uprawnienia i certyfikaty zawodowe poprawia się potencjał kształcenia zawodowego ze względu na możliwość ciągłej obserwacji rynku pracy, co pozwala na odpowiednią reakcję na zmieniające się jego wymogi (Emerling i in. 2010; Hermann-Pawłowska i in. 2015). Inną korzyścią oczekiwaną przez uczelnie, podejmujące się współpracy z profesjonalnymi organizacjami akredytującymi i certyfikującymi programy nauczania, jest uzyskanie prestiżu wśród studentów oraz pracodawców. Jednak dostosowanie programów i sposobów nauczania do wymogów certyfikujących podmiotów może mieć również negatywne konsekwencje. Artykuł ten był próbą rozpoznania jednej z nich.

Analiza wyników badania ankietowego pozwala na sformułowanie wniosku, iż istnieje grupa studentów, dla których nie jest zasadne ponoszenie dodatkowych nakładów na naukę w zamian za ułatwienia w uzyskaniu zawodowych kwalifikacji nadawanych przez profesjonalne podmioty typu ACCA, CIMA czy CFA. Studenci ci postrzegają te kwalifikacje jako zbędne w przyszłej pracy zawodowej, ponieważ planują podjęcie pracy w małych przedsiębiorstwach bądź dla małych przedsiębiorstw. Wyjątkiem jest certyfikat dyplomowanego księgowego nadawany przez SKwP, który jest pożądany również przez studentów planujących pracę w sektorze MŚP. Należy ocenić to jako racjonalne podejście, ponieważ międzynarodowe organizacje oferują swoje kwalifikacje osobom zamierzającym rozwijać swoje kariery w dużych podmiotach (ACCA qualifications... 2016), a SKwP kieruje swoją ofertę przede wszystkim do księgowych pracujących lub zamierzających pracować $w$ małych $i$ średnich przedsiębiorstwach.

Podstawową konkluzją z przeprowadzonych badań jest wskazówka dla osób konstruujących programy nauczania oraz treści programowe - zasadne jest zróżnicowanie oferty edukacyjnej poprzez umożliwienie studiowania na kierunkach finansowych akredytowanych przez profesjonalne organizacje i bez takiej akredytacji. W każdym przypadku należy jednak uznać za właściwe działanie poprawiające jakość kształcenia, co jest skutkiem uzyskania certyfikatów dla całej uczelni lub jej wydziałów przez organizacje, takie jak: IACBE, AACSB, AMBA. 
Wyżej zaprezentowane wnioskowanie obarczone jest istotnymi ograniczeniami. Podstawowym czynnikiem negatywnie wpływającym na uogólnienie wnioskowania jest dobór i zakres próby respondentów. Choć nie ma bezpośrednich przesłanek wykluczających możliwość odniesienia rozpoznanych prawidłowości na inne grupy studentów, to jednak przebadana grupa studentów nie jest reprezentatywna.

\section{PIŚMIENNICTWO}

ACCA qualification - the future. Embracing change. Shaping futures. 2016. Londyn, ACCA.

Annisette M., Kirkham L.M. 2007. The advantages of separateness explaining the unusual professionuniversity link in English Chartered Accountancy. Crit. Persp. Acc. 18, 1-30.

Bucior G., Kujawski J. 2017. Podyplomowe studia „Rachunkowość ACCA - poziom profesjonalny” na Wydziale Zarządzania Uniwersytetu Gdańskiego. Folia Pomer. Univ. Technol. Stetin. 335(87)2, 41-50.

Bucior G., Spigarska E. 2017. Teaching of university-level accounting in collaboration with the entities certifying the accounting profession - the example of the Faculty of Management at The University of Gdansk. Barcelona, EDULEARN, 633-641.

Bucior G., Zackiewicz-Brunke B. 2015. Akredytacja ACCA na Wydziale Zarządzania Uniwersytetu Gdańskiego. Folia Pomer. Univ. Technol. Stetin. 319(79)2, 37-48.

Emerling A., Orlińska A., Węsierska S. 2010. Współpraca firm z sektorem edukacji. Raport z badania. Warszawa, KPMG.

Foundations in accountancy and the ACCA qualification an overview for employers. 2012. Londyn, ACCA.

Gryn M. 2011. Certyfikat dla finansisty. Forbes 11, 5-7.

Montano J., Anes J., Hassal T., Joyce J. 2001. Vocational skills in the accounting professional profile: the Chartered Institute of Management Accountants (CIMA) employers opinion. Acc. Educ. 10(3), 299-313.

Parlow H., Röchter A. 2016. Cooperation between business and academia in Germany. A critical analysis of new trends in designing integrated study programs based on e-learning. Univ. J. Educ. Res. 4(9), 1931-1938.

Pavlin S., Kesting T., Baaken T. 2016. An integrative view on higher education and University-Business Cooperation in the light of academic entrepreneurship. Eur. J. Educ. 51(1), 3-8.

Prewysz-Kwinto P., Voss G. 2016. Certyfikacja zawodu księgowego w Polsce w opinii studentów kierunku Finanse i Rachunkowość - wyniki badania empirycznego. Stud. Oecon. Posnan. 4(11), 228-243.

Reforma Szkolnictwa Wyższego. 2011. Warszawa, MNiSW.

Rezolucja Parlamentu Europejskiego z dnia 8 czerwca 2011 r. w sprawie europejskiej współpracy w dziedzinie kształcenia i szkolenia zawodowego służącej wspieraniu strategii „Europa 2020". 2011. DzUrz. UE C $380 \mathrm{E}$.

Ryan M. 2012. Podnoszenie jakości kształcenia i szkolenia zawodowego we współpracy z pracodawcami i sektorem szkolnictwa wyższego - pobudzanie współpracy pomiędzy światem edukacji, szkolenia i pracy, w: Rozwijanie współpracy pomiędzy kształceniem zawodowym, szkolnictwem wyższym i uczeniem się dorosłych w odpowiedzi na wyzwania uczenia się przez całe życie. Red. M. Polak. Warszawa, Fundacja Rozwoju Systemu Edukacji.

Szadziewska A., Kujawski J. 2016a. Knowledge of ACCA qualifications among the students of the certified "ACCA Accounting" programme, in: INTED 2016 Proceedings. Barcelona, IATED Academy, 8509-8518.

Szadziewska A., Kujawski J. 2016b. The factors influencing students' choice of other than the ACCA-accredited curricula at the University of Gdansk, in: EDULEARN 2016 Proceedings. Barcelona, IATED, 1833-1844. 
Świetla K. 2012. Certyfikaty z dziedziny rachunkowości, ich różnorodność oraz wymogi formalne warunkujące uzyskanie uprawnień, w: Rachunkowość. Dydaktyka i certyfikacja zawodu księgowego. Red. D. Dziawgo. Toruń, Wydaw. Nauk. UMK.

Walińska E., Michalak M. 2013. Akredytacja uczelni wyższych przez profesjonalne organizacje rachunkowości w warunkach deregulacji zawodu księgowego. Folia Pomer. Univ. Technol. Stetin. 72, 202-220.

Streszczenie. Celem artykułu jest zbadanie relacji pomiędzy planami zawodowymi studentów kierunku finanse i rachunkowość, studiujących na Wydziale Zarządzania Uniwersytetu Gdańskiego, a postrzeganiem przez nich działań uczelni polegających na uzyskaniu akredytacji i certyfikacji profesjonalnych podmiotów z branży finansowej. Przy wykorzystaniu badań, polegających przede wszystkim na badaniu ankietowym studentów, formułowane są odpowiedzi na pytania dotyczące postrzegania przez studentów znaczenia certyfikatów i kwalifikacji zawodowych w zależności od swoich planów zawodowych dotyczących w szczególności formy pracy lub wielkości firmy przyszłego pracodawcy. Analiza wyników badania ankietowego pozwala na sformułowanie wniosku, iż studenci planujący pracę w małych i średnich przedsiębiorstwach postrzegają kwalifikacje nadawane przez organizacje międzynarodowe, takie jak ACCA, CIMA czy CFA, jako zbędne w przyszłej pracy zawodowej. Dla tych studentów ponoszenie dodatkowych nakładów na naukę, w zamian za ułatwienia w uzyskaniu zawodowych kwalifikacji, nie jest zasadne. Podstawową konkluzją z przeprowadzonych badań jest wskazówka dla osób konstruujących strukturę programów nauczania oraz treści programowe - celowe jest zróżnicowanie oferty edukacyjnej poprzez umożliwienie studiowania na kierunkach finansowych akredytowanych przez profesjonalne organizacje, jak i bez takiej akredytacji. 